\title{
Seismic Behavior Investigations of the Haunched Joint with Ribbed Anchor Webs in CFDST Structures
}

yufen zhang

Hebei University of Technology https://orcid.org/0000-0002-4618-0137

Hongfan Bu ( $\sim$ hongfanbu@gmail.com )

Hebei University of Technology

Shengxi Cao

Norendar international ltd.

\section{Research Article}

Keywords: CFDST column, haunched joint, ribbed anchor web, cyclic loading test, seismic behavior, finite element simulation, parametric analysis

Posted Date: July 30th, 2021

DOl: https://doi.org/10.21203/rs.3.rs-699347/v1

License: (c) (i) This work is licensed under a Creative Commons Attribution 4.0 International License.

Read Full License 


\section{Abstract}

The haunched joint with ribbed anchor webs in the concrete-filled double steel tubular (CFDST) structure was proposed in this study. The CFDST column and the steel beam were connected by vertical ribbed webs, which were anchored inside the column and connected to the beam web by the bolted connection, and haunches were welded to shift plastic hinges from the joint core to beam ends. The cyclic loading test was conducted on three beam-to-column joint specimens. Seismic behaviors including failure modes, strain and stress responses, hysteretic curves, ductility, and energy dissipation capacity were respectively analyzed. Besides, a finite element (FE) modeling was completed by ABAQUS in consideration of geometric and material nonlinearity. The validity of FE modeling was checked by comparisons between FE results and test results, and research results confirmed that the beam-to-column rotation and the shear deformation in the joint core were small owing to the restriction from the configuration of haunches. Then parametric investigations on connection constructional details, geometric dimensions, material strength, and axial compression ratios, were made to study seismic behaviors of the haunched joint with ribbed anchor webs. It showed that the selected parameters except concrete strength had certain influences on bearing capacity, ductility, and energy dissipation, and corresponding practicable design suggestions were proposed for the application of haunched joints with ribbed anchor webs in CFDST structures.

\section{Introduction}

In comparison with the ordinary concrete-filled steel tubular (CFST) column, the concrete-filled double steel tubular column has higher bearing capacity and better fire resistance with a smaller cross-sectional area, which can be applied in high-intensity earthquake areas [1-5]. Besides effective confinement to core concrete, the CFDST column consisting of a square tube outside and a circular tube inside is conducive to connect with $\mathrm{H}$-shaped steel beams [6, 7]. Many existing connection types between square CFST columns and steel beams can be modified to fit CFDST columns. Among the research achievements, the vertical stiffener joint and the external diaphragm joint have been applied in the CFDST structure $[8,9]$.

As a kind of rigid joint in the CFST structure, the through-beam joint was studied through experimental investigations and FE analyses [10-14]. The relevant results showed that this joint type had a reliable force-transferring mechanism, large stiffness, sufficient ductility and great energy dissipation capacity. But there is an obstacle that the continuous steel beam is laborious to be fixed to the column, and the through beam even hinders concrete from flowing. Hence, a new connection using a through-core web to connect steel beams with the CFST column has been put forward. Chiew et al. [15] investigated the forcetransferring mechanism of the through-web joint, and the results revealed that most of shearing force was shifted to the joint core by the through-core web. Mirghaderi et al. [16] and Jeddi et al. [17] also proved that the through-core web played an important role in force-transferring. In view of special crosssectional characteristics of the CFDST column, discontinuous vertical ribbed webs welded on two sides of the inner tube can substitute the continuous ones to reinforce the beam-to-CFDST column connection. 
To avoid sudden collapse of joints during earthquakes, installing haunches is a useful constructional measure in seismic designs because it can enhance the joint stiffness and prevent plastic failure from columns [18-22]. A cyclic loading test on the steel moment-resisting connection with straight haunches was carried out by Lee et al. [23], and the strut effect of haunches was verified. Hoang et al. [24] employed T-shaped hammer heads to simplify the haunch fabrication, and this method conformed to the plastic design requirements specified in EN 1993-1-8 [25]. Meanwhile, welding haunches has been proved to be an economical constructional measure in beam-to-column joints to achieve essential mechanical performances [26-28]. Chu et al. [29] and Dong et al. [30] respectively investigated seismic behaviors of the steel beam-to-CFDST column joint and the steel joint stiffened by haunches, and the results showed that the installation of haunches improved energy dissipation capacity and ductility.

In this study, haunched joints with ribbed anchor webs, combining advantages of vertical ribbed webs and haunches, were designed to be a rigid joint in CFDST structures. Three joint specimens were manufactured for cyclic loading tests, and failure modes, ultimate bearing capacity, initial stiffness, ductility, and other indexes were analyzed. Afterwards, a series of FE models were established and the obtained FE simulation results were verified by comparing with test results, then parametric analyses on seismic behaviors were conducted based on FE models.

\section{Test Overview}

\subsection{Design of specimens}

The plan of the joint specimen is shown in Fig. 1(a), and dimensions of the ribbed anchor web are shown in Fig. 1(b). Vertical ribbed webs through slots of the square steel tube were welded on the circular steel tube, and then connected to beam webs using bolted connections. Haunches and other plates were welded to steel tubes, as shown in the cutaway views (Figs. 1(c), 1(d)). Following the design criterion of "strong column \& weak beam", cross-sectional dimensions of the inner and the outer steel tubes were designed as $194 \mathrm{~mm} \times 6 \mathrm{~mm}$ and $\square 280 \mathrm{~mm} \times 10 \mathrm{~mm}$, respectively. For the steel beams, two crosssectional dimensions were selected to study the influence of cross-sectional dimensions on seismic behaviors of the joint. One was $\mathrm{H} 346 \mathrm{~mm} \times 174 \mathrm{~mm} \times 6 \mathrm{~mm} \times 9 \mathrm{~mm}$ for Specimen SPJ1, and the other one was $\mathrm{H} 350 \mathrm{~mm} \times 175 \mathrm{~mm} \times 7 \mathrm{~mm} \times 11 \mathrm{~mm}$ for Specimens SPJ2, SPJ3. As for Specimen SPJ3 shown in Fig. $1(d)$, stiffening diaphragms were set between the two tubes to investigate differences in the force transfer path based on that in Specimen SPJ2. The CFDST column was $2070 \mathrm{~mm}$ high, and the joint specimen was $3700 \mathrm{~mm}$ long. The main design parameters of each joint specimen are shown in Table 1. 
Table 1

Parameters of each joint specimen

Specimen No. Anchor components

Dimensions of the steel beam

$\begin{array}{lll}\text { SPJ1 } & \text { Vertical ribbed webs } & \mathrm{H} 346 \times 174 \times 6 \times 9 \\ \text { SPJ2 } & \text { Vertical ribbed webs } & \mathrm{H} 350 \times 175 \times 7 \times 11 \\ \text { SPJ3 } & \text { Vertical ribbed webs and stiffening diaphragms } & \mathrm{H} 350 \times 175 \times 7 \times 11\end{array}$

\subsection{Material properties}

The tensile coupon test for steel components was carried out in the light of requirements in GB/T 228.12010 [31]. The uniaxial compressive strength of $150 \times 150 \times 150 \mathrm{~mm}^{3}$ concrete samples was designed as $60 \mathrm{MPa}$. The actual material properties are represented in Table 2, where the average value of three test samples was taken as the measured value.

Table 2

Material properties

\begin{tabular}{|c|c|c|c|}
\hline Components & $\begin{array}{l}\text { Yield strength } \\
(\mathrm{MPa})\end{array}$ & $\begin{array}{l}\text { Ultimate strength } \\
(\mathrm{MPa})\end{array}$ & $\begin{array}{l}\text { Young's modulus } \\
(\mathrm{MPa})\end{array}$ \\
\hline Square steel tubes & 337.90 & 460.38 & $2.13 \times 10^{5}$ \\
\hline Circular steel tubes & 343.88 & 443.45 & $2.11 \times 10^{5}$ \\
\hline Vertical ribbed webs & 284.51 & 400.79 & $1.98 \times 10^{5}$ \\
\hline Haunch plates & 295.51 & 406.89 & $2.13 \times 10^{5}$ \\
\hline Beams H346×174×6×9 & 288.69 & 405.41 & $2.00 \times 10^{5}$ \\
\hline Beams H350×175×7×11 & 327.64 & 465.01 & $2.17 \times 10^{5}$ \\
\hline Concrete & / & 60.80 & $3.61 \times 10^{4}$ \\
\hline
\end{tabular}

\subsection{Test apparatuses and the loading scheme}

Test apparatuses are shown in Fig. 2. The column bottom was fixed on the foundation by the hinged support, and the vertical hinged support was installed at beam ends to ensure free rotation and horizontal displacement of the beams in a specified plane. The lateral bracing was placed in case of torsion and overturn of beams. The axial static load $(N)$ acted on top of the column via a hydraulic jack. The axial compression ratio in the test was determined to be 0.275 , which was written as $n=N / N_{u}$, and $N_{u}$ represented the ultimate axial bearing capacity of the CFDST column according to the calculation 
formula proposed by Zhang and Zhang [32]. Afterwards, lateral cyclic loads were applied to the top of the CFDST column by a horizontal actuator. During the loading process, a whole loading cycle was southward pushed first, then unloaded to the original point, and northward pulled again, finally unloaded. The southward push was regarded as the positive direction, and the northward pull reversed.

The lateral cyclic loads were determined by the force and displacements in turn. For the early loading, namely the elastic stage, the lateral force was $30 \mathrm{kN}$ as one load grade, and it gradually increased until the lateral displacement of the column top reached the estimated yield displacement. The estimated yield displacement was given by $\Delta_{e y}=P_{u} / K_{\text {sea }}$ where $P_{u}$ was the estimated moment capacity of the column under monotonic bending $\left(M_{u}\right)$ divided by the column height, and $K_{s e c}$ was secant stiffness of the forcedisplacement curve when the lateral force reached to $0.7 P_{u}$. In the inelastic stage, the lateral load was determined by the displacement with an increment of $0.5 \Delta_{e y}$ at each load step. The load step with the same displacement amplitude cycled twice until specimens were destroyed or the measured force decreased to less than $85 \%$ of the peak force.

The layout of measuring points for three joint specimens was the same. Figure 3(a) shows eight displacement meters for measuring the lateral displacement of the column, the shear deformation at the joint core, and the rotation angle of beam-to-column ( $h$ denotes the beam height). Figure 3(b) shows the layout of uniaxial strain gauges for measuring strains of steel components where probable large deformations appeared.

\section{Finite Element Models}

FE modeling with the same test conditions was conducted via ABAQUS program, so as to further analyze influences of different parameters on seismic behaviors of the connection. The constitutive relation of materials, boundary conditions, and interactions between different components were reasonably modeled, and corresponding details were elaborated as follows.

\subsection{Constitutive relation of steel}

The combined isotropic-kinematic hardening plastic behavior was selected to model the constitutive relation of steel components. The Poisson's ratio was set as 0.27 in line with the tensile coupon tests. Abdel-Rahman and Sivakumaran [33] evaluated the constitutive relations at the flat area and the corner area of channel steel, and the constitutive model proposed in that investigation was adopted for the square steel tube. Meanwhile, the constitutive model of the circular steel tube was established based on that of the flat area. The constitutive relations of the $\mathrm{H}$-shaped steel beams, haunches, ribbed anchor webs, connecting plates, bolts, and stiffening diaphragms were simplified to trilinear models based on the tensile coupon tests.

\subsection{Constitutive relation of concrete}


The concrete damaged plasticity model was adopted to simulate mechanical behaviors of concrete. Young's modulus was derived from the material property tests, and Poisson's ratio was 0.2 . In the test, the filled concrete in the column was subjected to three-dimensional compression due to the confinement from the steel tube, so a confinement effect factor [34] was introduced to compute the compressive stress-strain relation of concrete. Afterwards, the tensile constitutive relation of the concrete referred to GB/T 50010 - 2010 [35]. In accordance with the measurement method of concrete damage parameters [36], the concrete damage parameters applicable to ABAQUS were employed to model the plastic damage.

\subsection{Element type and meshes}

C3D8R was assigned to the element type of each instance in the FE model. For all instances, the structured method was chosen for the mesh generation based on detailed partition cells. The meshes in the beam-to-column conjunction area were finer than other areas because it can prevent erroneous element behavior particularly at key areas with large deformations.

\subsection{Boundary conditions and interaction properties}

"Tie" constraint was used to model welding between the steel components. The pretension force was applied by creating the bolt load. The surface-to-surface contact considering finite sliding was employed to model the interaction between steel and concrete. In the interaction property, "Penalty" was selected as the friction formulation. The isotropic friction coefficient was 0.6 based on the FE modeling presented by Han et al. [34], and "Hard contact" was employed as the criterion of pressure-overclosure in the normal behavior. The welded vertical webs were embedded in concrete because there was no sliding and rotations between interfaces. A batch of half-models was established because boundary conditions in the test were symmetric based on the south-north plane, and the overview of a half-model is shown in Fig. 4. In accordance with the test loading mode, three steps were made to apply the bolt load, axial compressive force and cyclic lateral load in succession.

\section{Analyses Of Seismic Behaviors}

\subsection{Failure modes}

The stress distribution and failure process of the joint specimens were clearly presented with FE simulations. The test phenomena and stress nephograms from FE simulations are compared in Fig. 5. When the lateral force reached the corresponding yield load, the measured strains were almost less than $1200 \mu \varepsilon$, showing that steel components did not yield yet. In the process of displacement loading, when the lateral displacements in the test reached $15 \sim 20 \mathrm{~mm}$, strains of outer tubes close to the lower haunches were $1500 \mu \varepsilon$, which approximated the yield strain of the steel tube. Figure 5(a) shows that stresses at this corresponding position exceed yield strength when the applied displacement is $20 \mathrm{~mm}$. When the lateral displacements in the test increased to $24 \sim 28 \mathrm{~mm}$, peeling of the steel beam surface was captured in Fig. 5(b). Likewise, the stress nephogram displays that stresses at the corresponding 
position are larger than that at the vicinity. For the lateral displacements of $37 \sim 41 \mathrm{~mm}$, the beam flange slowly bulged, and the test photo together with the FE stress nephogram are shown in Fig. 5(c). As the lateral displacements further increased to $42 \sim 54 \mathrm{~mm}$, the plastic hinge was formed by the bulge development of beam flange. At the end of the loading, the displacements were $52 \sim 65 \mathrm{~mm}$, and obvious cracks emerged in the beam flange near the butt weld, as shown in Fig. 5(d), and stress values of this part shown in the stress nephogram are higher than the ultimate strength of the beam flange. Figure 6 shows the failure mode of the proposed joint that a plastic hinge forms at the beam end. The final test phenomena also proved that the structure of the haunched joint with ribbed anchor webs built a rigid beam-to-column connection because ribbed anchor webs inside the CFDST column were not pulled out or snapped. Meanwhile, the rotation angle between the beam and the column, and the shear deformation of the joint core area were very small owing to the restriction from the configuration of haunches.

\subsection{Strain and stress responses}

There was no significant difference in strains of outer steel tubes of the three specimens, but it was different for strains of inner steel tubes of Specimens SPJ2, SPJ3 in the case of the same steel beams. The general relation between the lateral force $(P)$ and strain $(\varepsilon)$, including vertical strains and circumferential strains from the upper measuring point on the inner tube, can be reflected by skeleton curves represented in Fig. 7. In addition to identical ribbed anchor webs, additional stiffening diaphragms were installed in Specimen SPJ3 (see Figs. 1(c), 1(d)). Figure 7 shows that vertical strains of the inner tube are much larger than circumferential strains of the inner tube since the sum of confinement effect in the normal direction and circumferential bonding stress is stronger than the vertical bonding stress. For SPJ2, the selected measurement points were in the elastic state, while strains of the inner steel tube in SPJ3 were much higher and exceeded the yield strain. It attributed to that the stiffening diaphragms were conducive to shift internal force from beam ends to inner steel tubes, and the connected inner tube in SPJ3 worked sufficiently so that the internal force could be effectively distributed in a larger area of the inner tube rather than limited to the joint core area. Figure 8 shows stress nephograms of the two FE models at the failure state, and it also proves that the stress distribution in SPJ3 is more uniform than that in SPJ2 due to the configuration of stiffening diaphragms, and stresses in ribbed anchor webs of SPJ2 are much larger than stresses in ribbed anchor webs of SPJ3. The dissipated energy also increased due to stiffening diaphragms, which is discussed in the following sections. In brief, cross-sectional characteristics of the CFDST column were exerted to redistribute the internal force in panel zone for the haunched joint with ribbed anchor webs, especially for that with stiffening diaphragms.

\subsection{Hysteretic curves}

The force $(P)$-displacement $(\Delta)$ hysteretic curves obtained from tests and FE simulations are represented in Fig. 9, and the latter is basically consistent with the former. In the elastic stage, there is little change in initial stiffness of each joint specimen, and the displacement linearly increases with the force. In the deformation development stage, hysteretic curves gradually change to be full and are hardly pinched, showing that the joint possesses sufficient energy dissipation performance. As the applied displacement increases, stiffness degenerates steadily due to increasing curvature of bending beam flanges near 
haunches. Meanwhile, small deformations of CFDST columns were observed in tests and captured in FE simulations, respectively. The lateral displacement at the peak point of the three specimens is about 40 $\mathrm{mm}$, which indicates there is a small beam-to-column rotation. It shows that the haunched joint with ribbed anchor webs has large stiffness to restrict the ultimate deformation. As for the failure stage, the measured force drops sharply as the lateral displacement increases owing to the fracture of butt welds in steel beams, while hysteretic curves obtained from FE simulations decrease slowly.

\subsection{Skeleton curves}

The skeleton curves obtained from tests and FE simulations are shown in Fig. 10, and it can be seen that the curves obtained from FE simulations are roughly symmetric based on the origin. The ductility factor (u) for evaluating the ductility of the structure is a ratio of the failure displacement $\left(\Delta_{d}\right)$ divided by the nominal yield displacement $\left(\Delta_{y}\right)$, i.e., $u=\Delta_{d} / \Delta_{y}$. The nominal yield displacement obtained by the yield moment method is different from the estimated yield displacement in the loading scheme. A typical $P-\Delta$ skeleton curve and relevant characteristic points are shown in Fig. 11. $P_{y}, P_{\max }$ and $P_{d}$ respectively denotes the nominal yield force, the peak force, and the failure force.

Synthesizing the positive direction and the negative direction of skeleton curves from tests, the force and displacement corresponding to each characteristic point, and ductility factors are indicated in Table 3. Figures 10(a), 10(b) illustrate that initial stiffness is almost identical whether in tests or FE simulations. In Table 3, the mean error of the ultimate bearing capacity between FE simulations and tests is $2.49 \%$; the maximum error is $6.37 \%$. Meanwhile, the average ductility factor derived from tests is 2.21 , and it is smaller than what was derived from FE simulations because the weld defects and the residual stress in weld seams made specimens easy to fail in tests. Although there are a few differences in ductility between tests and FE simulations, both are mutually validated with respect to the failure process, initial stiffness, ultimate resistance capacity, and hysteretic curve shape. The test data show that the ultimate bearing capacity of Specimen SPJ2 is $16.38 \%$ higher than that of Specimen SPJ1 because crosssectional dimensions of the steel beams in SPJ2 are larger. And the ultimate resistance capacity of Joint SPJ3 with stiffening diaphragms is enhanced by $5.58 \%$ than that of Specimen SPJ2, so though stiffening diaphragms with a small cross-sectional area were installed only between double tubes, it still improved the ultimate strength of the joint. 
Table 3

Bearing capacity and ductility factors of each specimen

\begin{tabular}{|c|c|c|c|c|c|c|c|c|c|}
\hline \multicolumn{3}{|c|}{ Specimen } & \multicolumn{2}{|c|}{ Yield point } & \multicolumn{2}{|l|}{ Peak point } & \multicolumn{2}{|c|}{ Failure point } & \multirow[t]{2}{*}{$u$} \\
\hline & & & $P_{y}(\mathrm{kN})$ & $\Delta_{y}(\mathrm{~mm})$ & $P_{\max }(\mathrm{kN})$ & $\Delta_{m}(\mathrm{~mm})$ & $P_{d}(\mathrm{kN})$ & $\Delta_{d}(\mathrm{~mm})$ & \\
\hline \multirow[t]{3}{*}{ SPJ1 } & \multicolumn{2}{|c|}{ FE simulation } & 349.8 & 24.2 & 400.6 & 43.6 & 320.4 & 70.4 & 2.91 \\
\hline & \multirow[t]{2}{*}{ Test } & Push & 282.4 & 19.4 & 345.6 & 34.5 & 276.4 & 45.3 & 2.34 \\
\hline & & Pull & 369.8 & 25.1 & 407.6 & 35.7 & 326.1 & 52.8 & 2.10 \\
\hline \multirow[t]{3}{*}{ SPJ2 } & \multicolumn{2}{|c|}{ FE simulation } & 408.7 & 25.5 & 440.1 & 44.0 & 352.1 & 64.7 & 2.54 \\
\hline & \multirow[t]{2}{*}{ Test } & Push & 370.9 & 26.3 & 436.1 & 40.2 & 348.9 & 55.2 & 2.10 \\
\hline & & Pull & 393.0 & 27.6 & 440.5 & 39.5 & 352.4 & 57.7 & 2.09 \\
\hline \multirow[t]{3}{*}{ SPJ3 } & \multicolumn{2}{|c|}{ FE simulation } & 417.4 & 26.5 & 459.5 & 50.2 & 367.6 & 72.8 & 2.75 \\
\hline & \multirow[t]{2}{*}{ Test } & Push & 395.3 & 26.1 & 457.1 & 40.6 & 366.1 & 62.4 & 2.39 \\
\hline & & Pull & 418.9 & 25.9 & 468.4 & 36.7 & 374.7 & 58.1 & 2.24 \\
\hline
\end{tabular}

\subsection{Energy dissipation performance}

The equivalent viscous damping coefficient $h_{e}$ and the dissipated energy in a half loading cycle $E_{t}$ (the area enclosed by half of a hysteresis loop) were utilized to assess the energy dissipation performance. For each specimen, changes of $h_{e}$ at each half-cycle number are shown in Fig. 12, where $i$ represents the number of half hysteresis loops. At the failure point, $h_{e}$ is $0.273,0.280$, and 0.295 for SPJ1, SPJ2, and SPJ3 respectively. The changes of $E_{t}$ at each half hysteresis loop are shown in Fig. 13. The energy dissipation of specimens rose with the increase of the loading loop, proving that plastic hinges at beam ends absorbed a lot of energy. And the curves show that the energy dissipation capacity of SPJ2 is basically equal to that of SPJ1, but the energy dissipation capacity of SPJ3 is much greater than that of SPJ2. Therefore, an increase of cross-sectional dimensions of the steel beam only had a slight improvement in the energy dissipation capacity owing to the same connection structure, but installing the anchor component such as stiffening diaphragms contributed to the improvement of energy dissipation capacity. Therefore, although the stiffening diaphragm between the double tube has a small crosssection, and it may also influence the concrete flowing, it can make good use of the special sectional characteristic of CFDST column to aim at the improvement of energy dissipation for this type of joint.

\section{Parametric Analyses}

The aforementioned analyses demonstrate that FE simulation results are consistent with test results, so a series of FE models were established to further analyze how different parameters affect seismic behaviors of the proposed joint type. The selected parameters include constructional details, geometric dimensions, material strength of steel and concrete, and axial compression ratios $(n)$, as shown in Table 
4. In every group, the superscript " $*$ " represents the parameter derived from test specimen SPJ2, and other corresponding parameters were changed based on Specimen SPJ2. The first quadrant of $P-\Delta$ skeleton curves obtained by FE simulations was used for parametric analyses due to the symmetry based on the origin.

Table 4

Parameter settings

\begin{tabular}{|c|c|c|}
\hline Types & Parameters & Contents \\
\hline \multirow[t]{3}{*}{ Constructional details } & With both ribs and haunches & SPJ2* ${ }^{*}$ \\
\hline & Only with ribs & SPJ2-H \\
\hline & No ribs and no haunches & SPJ2-HS \\
\hline Geometric dimensions & $\begin{array}{l}\text { Beam-to-column bending stiffness ratios } \\
\text { per unit length }(k)\end{array}$ & $0.3,0.41^{\star}, 0.5,0.6$ \\
\hline \multirow[t]{2}{*}{ Material strength } & Steel beam strength & $\begin{array}{l}\text { Q235*, Q345, Q420, } \\
\text { Q550 }\end{array}$ \\
\hline & Concrete strength & $\begin{array}{l}\mathrm{C} 40, \mathrm{C} 50, \mathrm{C} 60^{*}, \mathrm{C} 80, \text { No- } \\
\text { concrete }\end{array}$ \\
\hline $\begin{array}{l}\text { Compressive force on the } \\
\text { column top }\end{array}$ & Axial compression ratios $(n)$ & $\begin{array}{l}0.04,0.275^{\star}, 0.4,0.5 \\
0.6\end{array}$ \\
\hline
\end{tabular}

\subsection{Influences of constructional details}

In the test, haunches and vertical ribbed webs were installed in three joint specimens to build an effective connection, and the influence of stiffening diaphragms was analyzed according to test results. The seismic behaviors of the proposed joint with different constructional details were further studied based on corresponding FE models. Haunches in Model SPJ2-H were removed, and vertical ribbed webs were direct force-transferring components; while all ribs and haunches were removed for Model SPJ2-HS. Figure 14 shows different failure modes obtained from these three models. The bulging column and the plastic hinges near the CFDST column were captured in Model SPJ-HS. For Model SPJ-H, bulges of the column were effectively alleviated, and the plastic hinges were shifted outside in comparison with the failure phenomenon of Model SPJ2-HS. Moreover, the ribs had small bulges along the hypotenuse, which absorbed a part of energy during the cyclic loading process. And for Model SPJ2, an ideal failure mode of plastic hinges formed at beam ends was captured as expected. Meanwhile, the stress concentration at the core area significantly decreased and there was no bulge on the outer steel tube. $P$ - $\Delta$ hysteretic curves shown in Fig. 15 present different degrees of full loops. $h_{e}$ is $0.139,0.438,0.161$ respectively for Models SPJ2-HS, SPJ2-H, and SPJ2 at the peak load point. Therefore, the vertical ribbed web joint has the higher energy dissipation capacity, while the joint without ribs and haunches has the lower one. These failure mechanisms and energy dissipation performance have some relationships to the deformation ability, as 
shown in the skeleton curves in Fig. 16. The initial stiffness of Model SPJ2 was improved by $15.91 \%$ than that of Model SPJ2-H, and was improved by $52.96 \%$ than that of Model SPJ2-HS. The ultimate bearing capacity of Model SPJ2 was increased significantly (31.42\% higher than SPJ2-H and $69.60 \%$ higher than SPJ2-HS). The contrastive analysis demonstrates that haunches and ribs have constructive effects on seismic behaviors of the haunched joint with ribbed anchor webs under cyclic loading.

\subsection{Influences of beam-to-column bending stiffness ratios per unit length $(k)$}

The beam-to-column bending stiffness ratios per unit length $(k)$ for parametric analyses were $0.3,0.41$, 0.5 , and 0.6 . Herein $k$ was affected by the length of the steel beam with the same cross-sectional dimension. Hence, the beam length was $5057 \mathrm{~mm}, 3700 \mathrm{~mm}, 3034 \mathrm{~mm}$, and $2528 \mathrm{~mm}$ respectively, and the cross-sectional dimensions was $\mathrm{H} 350 \times 175 \times 7 \times 11 \mathrm{~mm}^{4}$. The failure mode of all FE models was ideal as plastic hinges were captured at beam ends. Figure 17 shows corresponding $P$ - $\Delta$ skeleton curves obtained from FE simulations. It indicates that $k$ controlled by the beam length within a range affected the ultimate bearing capacity and initial stiffness because shortening beam length restricted the rotation radius of the joint under cyclic loading. When $k=0.41,0.5,0.6$, the ultimate resistance capacity was improved by $9.88 \%, 15.55 \%$, and $16.77 \%$ respectively in comparison with Model of $k=0.3$, and initial stiffness was improved by $6.03 \%, 32.51 \%$, and $42.45 \%$. The differences in the two indexes between Models of $k=0.5$ and $k=0.6$ were not evident. Therefore, the value of $k$ from 0.3 to 0.5 is fit for this joint type to perform excellent seismic behaviors, and could meet the engineering requirement of "strong column \& weak beam".

\subsection{Influences of steel beam strength}

The steel grade of the steel beam was Q235 in the test, and Q345, Q420, and Q550 were considered in FE simulations to analyze influences of steel beam strength, and the models were labeled by Q345, Q420, Q550. Figure 18 shows $P$ - $\Delta$ skeleton curves of corresponding joint models. The nominal yield displacements increased successively for increasing steel beam strength, and the ultimate resistance capacity of Models Q345, Q420, Q550 was respectively improved by $17.32 \%, 27.77 \%, 47.94 \%$ than that of Model Q235. However, initial stiffness was almost unchanged since cross-sectional dimensions and Young's modulus of all steel beams were equal, and the ductility was smaller for the joint model with larger steel beam strength. Figure 19 only contains stress nephograms of Models Q420 and Q550, because Models Q345 and Q420 had similar stress nephograms and the same failure mode that plastic hinges occurred at beam ends and small bulges appeared on outer tube walls. As can be seen in Fig. 14(c) and Figs. 19(a), 19(b), stresses in ribbed anchor webs, steel beams, and outer steel tubes rose significantly when steel beam strength increased, and it caused larger deformations at these positions. For Model Q550, the failure mode was changed to local buckling of steel beams and distinct bulges of the outer tube wall. The growing internal force in steel beams was transmitted to the internal CFST column only via ribbed anchor webs. Therefore, the inner tube and core concrete were less stressed due to an insufficient force transmission, and stresses gradually accumulated and mainly concentrated on steel beams, ribbed anchor webs, until the outer tube.

Page $11 / 26$ 
Besides, according to constructional details of the Specimen SPJ3, stiffening diaphragms was added on Model Q550 to form the new model Q550+, and its failure mode is represented in Fig. 19(c). The whole CFDST column worked as a whole through stiffening diaphragms between two tubes. Meanwhile, the stress concentration area and the bulging part of the outer tube were reduced, and the ductility was better than that of Model Q550 because the internal force from beams was more effectively transmitted to the internal CFST column via stiffening diaphragms. The bearing capacity of Model Q550 + was also improved by $7.65 \%$ than that of Model Q550. Therefore, it is practicable to install stiffening diaphragms to enhance ductility and bearing capacity especially when the steel beam strength is large.

\subsection{Influences of concrete strength}

The uniaxial compressive strength of concrete cubes was selected as $40 \mathrm{MPa}, 50 \mathrm{MPa}, 60 \mathrm{MPa}$, and 80 MPa to compute the constitutive relation and model mechanical behaviors of the joint with different concrete strength, and a model without concrete was adopted for a comparison. All the models were labeled by the different concrete $\mathrm{C} 40 \sim \mathrm{C} 80$, and No-concrete. Figure 20 shows the $P-\Delta$ skeleton curve of each joint model. There was a sharp degeneration in initial stiffness and ultimate resistance capacity for Model No-concrete, since concrete improved the rigidity of the column and the globality the joint. The initial stiffness and the ultimate resistance capacity of Model C40 were $102.87 \%$ and $112.46 \%$ respectively higher than those of Model No-concrete. However, for the joint models with CFDST columns, there was a slight improvement in initial stiffness and ultimate bearing capacity when concrete strength increased. The stress nephograms and failure modes of Models C40, C50, C60, and C80 were extremely similar, so only the stress nephogram of Model C40 and that of Model No-concrete are represented in Fig. 21. The column of Model No-concrete bulges, and the bulging position is near the haunch because the hollow thin-walled column under compression is prone to instability and buckling especially for the area of sudden changes in bending stiffness. In the final failure stage, the steel beam was still in a good state without stress concentration and large deformation when the column was failed (Fig. 21(b)). It is concluded from this contrastive analysis that the haunched joint with ribbed anchor webs is applicable for the CFDST structure but not for the steel structure, and using low strength concrete to reduce construction budget based on engineering requirements is practicable.

\subsection{Influences of axial compression ratios ( $n)$}

The axial compressive force on the CFDST column is an important factor affecting seismic performance of the haunched joint with ribbed anchor webs. Therefore, the values of $n(0.04,0.275,0.4,0.5$ and 0.6$)$ were considered in FE simulations. Figure 22 presents corresponding $P$ - $\Delta$ skeleton curves. The results illustrated that $n$ influenced joint initial stiffness, ultimate resistance capacity, ductility, and deformation resistance. When $n=0.275,0.4,0.5$ and 0.6 , initial stiffness was enhanced by $25.08 \%, 59.82 \%, 87.49 \%$, and $162.70 \%$ respectively in comparison with that of Model of $n=0.04$. As for the ultimate resistance capacity, it enhanced $6.21 \%, 7.71 \%, 15.64 \%$, and $21.60 \%$, respectively. It was attributed to that the confinement effect on concrete from double steel tubes was enhanced as the increase of axial compressive force. In addition, there was a sharper fall in the $P$ - $\Delta$ skeleton curve after each peak point with the increase of the axial compressive force, accordingly showing a decrease of deformation 
resistance and ductility. The reason was that the increasing axial compressive force caused larger bending moment once the lateral displacement increased steadily.

When $n=0.04,0.275,0.4$, failure modes of the joint models were that plastic hinges generated at beam ends, while failure modes of the joint models were the buckling failure of the CFDST column and bulge phenomena on the outer tube wall when $n=0.5$ and 0.6. The two different failure modes are represented in Fig. 23. Therefore, the axial compression ratio under 0.5 is better to prevent the buckling failure and bulges of the CFDST column, so as to guarantee sufficient ductility in seismic designs for the haunched joint with ribbed anchor webs.

\section{Conclusions}

Three haunched joints with ribbed anchor webs were tested under lateral cyclic loads, and failure modes, strain and stress responses, hysteretic curves, and energy dissipation performance were analyzed. The effective constitutive relations of materials, the reasonable element type and meshes, the identical boundary conditions, and appropriate interactions were selected to conduct FE simulations by ABAQUS. FE simulations were validated by test results, then a series of parametric analyses were carried out based on Model SPJ2. The main conclusions are as follows:

1. Failure mode of the haunched joint with ribbed anchor webs was plastic hinges at steel beam ends. The position was far from the joint core area owing to the installation of haunches. The deformation in joint specimens concentrated at steel beams and there was a little damage to columns, and it indicated that this connection type for the CFDST column met the criterion of "strong column \& weak beam". The hysteretic curves were full and there was almost no pinch phenomenon. The final equivalent viscous damping coefficients were $0.273 \sim 0.295$, which manifested that the tested joints had excellent energy dissipation capacity. The ultimate bearing capacity was increased as the improvement of the cross-sectional dimensions of steel beam; stiffening diaphragms with a small cross-sectional area still improved the ultimate strength of the joint, and improved ductility and energy dissipation capacity particularly.

2. FE simulation results coincided with test results with respect to failure modes, hysteretic curves, and skeleton curves. The mean error for the ultimate bearing capacity was $2.49 \%$, and the maximum error for that was $6.37 \%$. The synthetic analyses further confirmed that the proposed joint type was reliable and rigid, which performed great seismic behaviors under cyclic loading.

3. Parametric analyses showed that different parameters had different influences on seismic behaviors of the haunched joint with ribbed anchor webs, and then optimal design suggestions were listed as follows. Besides ribs and haunches, stiffening diaphragms are practicable to connect the double tubes especially for the high strength steel beam; beam-to-column bending stiffness ratio per unit length is appropriate to be $0.3 \sim 0.5$ to exert good mechanical performances; choosing low strength grade of concrete is allowed to satisfy engineering requirements; the axial compression ratio should be limited within 0.5 . 


\section{References}

1. Huang H, Han LH, Tao Z, Zhao XL (2010) Analytical behaviour of concrete-filled double skin steel tubular (CFDST) stub columns. J Constr Steel Res 66:542-555.

https://doi.org/10.1016/j.jcsr.2009.09.014

2. Huang H, Han LH, Zhao XL (2013) Investigation on concrete filled double skin steel tubes (CFDSTs) under pure torsion. J Constr Steel Res 90:221-234. https://doi.org/10.1016/j.jcsr.2013.07.035

3. Li MH, Zong ZH, Hao H, Zhang XH, Lin J, Xie GY (2019) Experimental and numerical study on the behaviour of CFDST columns subjected to close-in blast loading. Eng Struct 185:203-220. https://doi.org/10.1016/j.engstruct.2019.01.116

4. Pagoulatou M, Sheehan T, Dai XH, Lam D (2014) Finite element analysis on the capacity of circular concrete-filled double-skin steel tubular (CFDST) stub columns. Eng Struct 72:102-112. https://doi.org/10.1016/j.engstruct.2014.04.039

5. Wang J, Cheng XF, Wu C, Hou CC (2019) Analytical behavior of dodecagonal concrete-filled double skin tubular (CFDST) columns under axial compression. J Constr Steel Res 162:584-597. https://doi.org/10.1016/j.jcsr.2019.105743

6. Han LH: Concrete Filled Steel Tubular Structures-Theory and Practice (Third Edition). Science Press, Beijing (2016) (in Chinese)

7. Hu Y, Zhao JH, Zhang DF, Chen C (2019) Experimental seismic performance of CFDST-steel beam frames with different construction details. J Constr Steel Res 162:613-627. https://doi.org/10.1016/j.jcsr.2019.105736

8. Zhang YF, Zhang DF, Demoha K: Internal force transfer mechanism and bearing capacity of vertical stiffener joints in CFDST structures. Adv. Mater. Sci. Eng. 2019, 2105365 (2019) https://doi.org/10.1155/2019/2105365

9. Zhang YF, Jia HX, Li YY, Demoha K (2020) Experiments on cyclic performance of external diaphragm joints between CFDST columns and steel beams. B Earthq Eng 18:3843-3861. https://doi.org/10.1007/s10518-020-00844-w

10. Azizinamini A, Schneider SP: Moment connections to circular concrete-filled steel tube columns. J. Struct. Eng. 130, 213-222 (2004) https://doi.org/10.1061/(ASCE)0733-9445(2004)130:2(213)

11. Mirghaderi SR, Renani MD (2008) The rigid seismic connection of continuous beams to column. J Constr Steel Res 64:1516-1529. https://doi.org/10.1016/j.jcsr.2008.01.015

12. Sheet IS, Gunasekaran U, MacRae GA (2013) Experimental investigation of CFT column to steel beam connections under cyclic loading. J Constr Steel Res 86:167-182. https://doi.org/10.1016/j.jcsr.2013.03.021

13. Khanouki MMA, Sulong NHR, Shariati M, Tahir MM (2016) Investigation of through beam connection to concrete filled circular steel tube (CFCST) column. J Constr Steel Res 121:144-162. https://doi.org/10.1016/j.jcsr.2016.01.002 
14. Naserifard M, Vetr MG (2019) Parametric study on behavior of steel beam to reinforced concrete column connections in moment frames. Int J Steel Struct 19:1511-1520.

https://doi.org/10.1007/s13296-019-00226-2

15. Chiew SP, Lie ST, Dai CW (2001) Moment resistance of steel I-beam to CFT column connections. J Struct Eng 127:1164-1172. https://doi.org/10.1061/(ASCE)0733-9445(2001)127:10(1164)

16. Mirghaderi SR, Torabian S, Keshavarzi F (2010) I-beam to box-column connection by a vertical plate passing through the column. Eng Struct 32:2034-2048.

https://doi.org/10.1016/j.engstruct.2010.03.002

17. Jeddi MZ, Sulong NHR, Khanouki MMA (2017) Seismic performance of a new through rib stiffener beam connection to concrete-filled steel tubular columns: An experimental study. Eng Struct 131:477-491. https://doi.org/10.1016/j.engstruct.2016.10.038

18. Kurejková M, Wald F (2017) Design of haunches in structural steel joints. J Civ Eng Manag 23:765772. https://doi.org/10.3846/13923730.2017.1281838

19. Nasery MM, Hüsem M, Okur FY, Altunisik AC (2020) Damage effect on experimental modal parameters of haunch strengthened concrete-encased composite column-beam connections. Int $\mathrm{J}$ Damage Mech 29:297-334. https://doi.org/10.1177/1056789519843330

20. Saberi H, Kheyroddin A, Gerami M (2016) Welded haunches for seismic retrofitting of bolted T-stub connections and flexural strengthening of simple connections. Eng Struct 129:31-43. https://doi.org/10.1016/j.engstruct.2016.09.050

21. Saberi H, Saberi V, Kheyroddin A, Gerami M (2019) Seismic behavior of frames with bolted end plate connections rehabilitated by welded haunches under near-and far-fault earthquakes. Int J Steel Struct 19:672-691. https://doi.org/10.1007/s13296-019-00203-9

22. Tanaka N (2003) Evaluation of maximum strength and optimum haunch length of steel beam-end with horizontal haunch. Eng Struct 25:229-239. https://doi.org/10.1016/S0141-0296(02)00146-3

23. Lee CH, Jung JH, Oh MH, Koo ES (2003) Cyclic seismic testing of steel moment connections reinforced with welded straight haunch. Eng Struct 25:1743-1753. https://doi.org/10.1016/S01410296(03)00176-7

24. Hoang VL, Jaspart JP, Demonceau JF (2014) Hammer head beam solution for beam-to-column joints in seismic resistant building frames. J Constr Steel Res 103:49-60. https://doi.org/10.1016/j.jcsr.2014.08.001

25. EN 1993-1-8 (2005) Eurocode 3-Design of Steel Structures, Part 1-8: Design of Joints. European Committee for Standardization, Brussels

26. Lachal A, Aribert JM, Loho G: Static design and cyclic behaviour of end-plate steel and composite joints strengthened by haunches. Proc. Fourth Int. Conf. Adv. Steel Struct. 2, 1353-1358 (2005) https://doi.org/10.1016/B978-008044637-0/50201-8

27. Shanmugam NE, Ng YH, Liew JYR (2002) Behaviour of composite haunched beam connection. Eng Struct 24:1451-1463. https://doi.org/10.1016/S0141-0296(02)00093-7 
28. Yu QS, Uang CM, Gross J: Seismic rehabilitation design of steel moment connection with welded haunch. J. Struct. Eng. 126, 69-78 (2000) https://doi.org/10.1061/(ASCE)0733-

9445(2000)126:1(69)

29. Chu YP, Jia B, Zhou LL (2009) Seismic behavior study on connections of multi-barrel tube-confined concrete column with steel beam. J Southwest Univ Sci Technol 24:7-12. (in Chinese)

30. Dong JL, Wang Y, Zhuang P, Li QG (2016) Experimental study on seismic behaviors of steel frames with haunch reinforced section connections. China Civ Eng J 49:69-79. (in Chinese)

31. GB/T 228.1-2010 (2010) Metallic Materials-Tensile Testing, Part 1: Method of Test at Room Temperature. Standard Press of China, Beijing. (in Chinese)

32. Zhang YF, Zhang ZQ (2016) Study on equivalent confinement coefficient of composite CFST column based on unified theory. Mech Adv Mater Struct 23:22-27. https://doi.org/10.1080/15376494.2014.922650

33. Abdel-Rahman N, Sivakumaran KS: Material properties models for analysis of cold-formed steel members. J. Struct. Eng. 123, 1135-1143 (1997) https://doi.org/10.1061/(ASCE)07339445(1997)123:9(1135)

34. Han LH, Yao GH, Tao Z (2007) Performance of concrete-filled thin-walled steel tubes under pure torsion. Thin Wall Struct 45:24-36. https://doi.org/10.1016/j.tws.2007.01.008

35. GB/T 50010 - 2010 (2010) Code for Design of Concrete Structures. China Architecture \& Building Press, Beijing

36. Birtel V, Mark P: Parameterised finite element modelling of RC beam shear failure (2006) ABAQUS Users' Conference (2006)

\section{Figures}




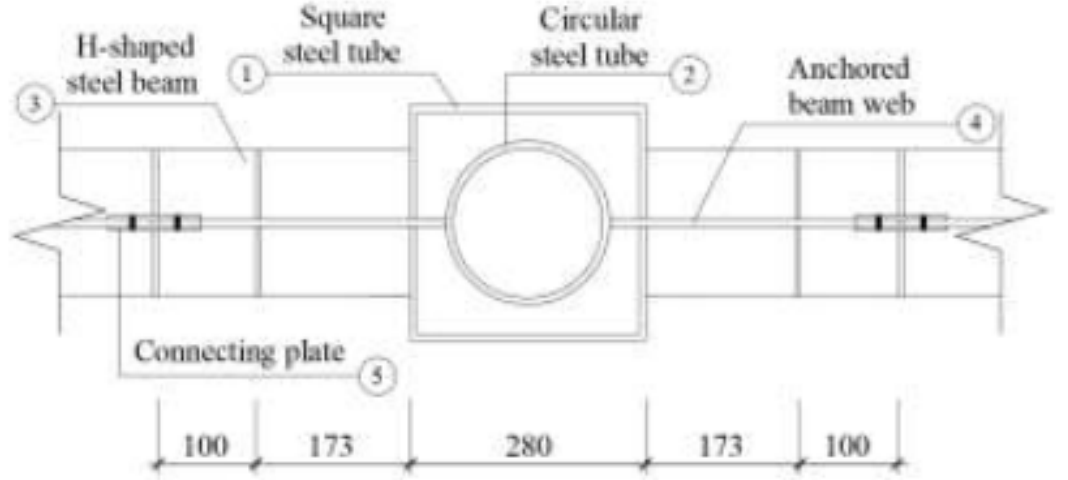

(a) Plan of the haunched joint with ribbed anchor webs

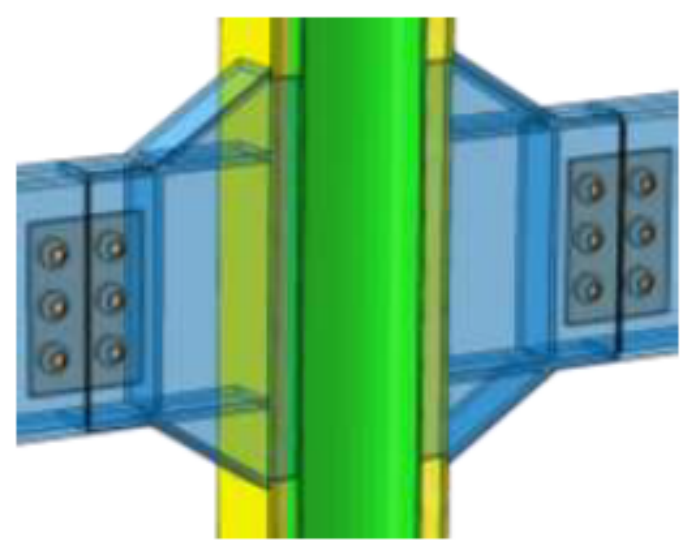

(c) Cutaway view of SPJ1, SPJ2

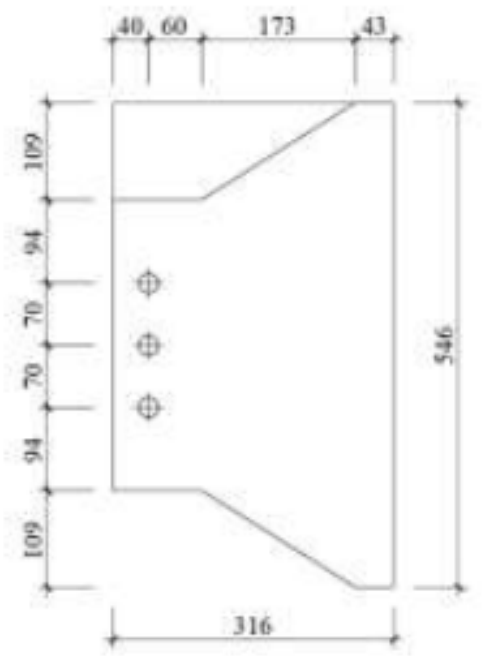

(b) Vertical ribbed web

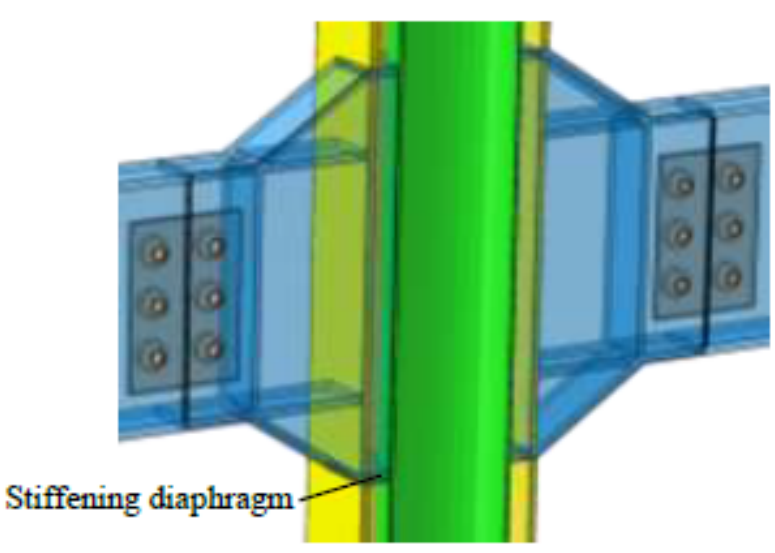

(d) Cutaway view of SPJ3

\section{Figure 1}

Dimensions and structures of specimens $(\mathrm{mm})$ 


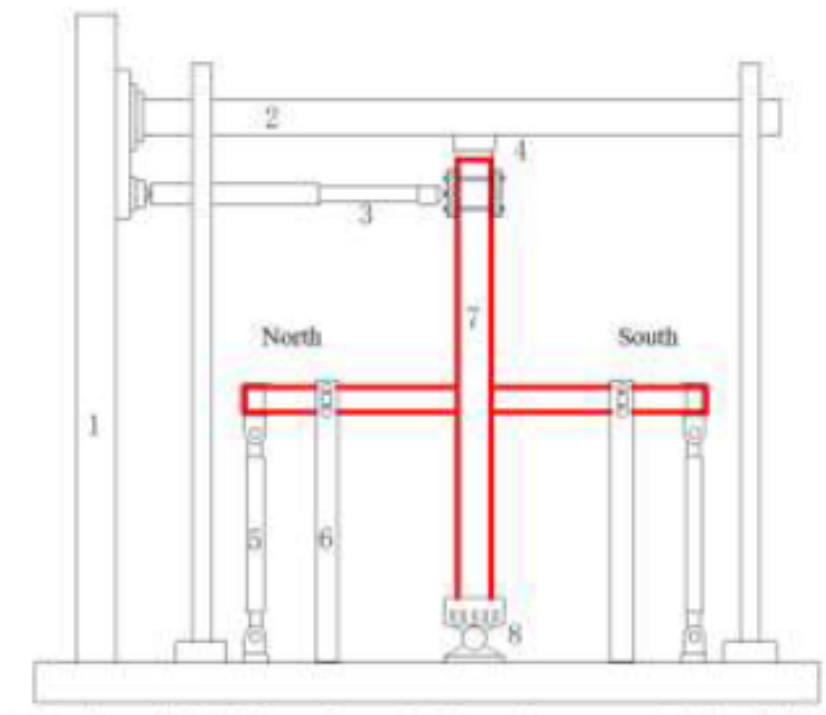

1 Reactioe wall 2 Rigid cossbesm 3 Reciprocatiog actuator 4 Hydranlic jack 5 Vertical hinged support 6 Lateral support 7 Specimien 8 Hinged support

(a) Loading device

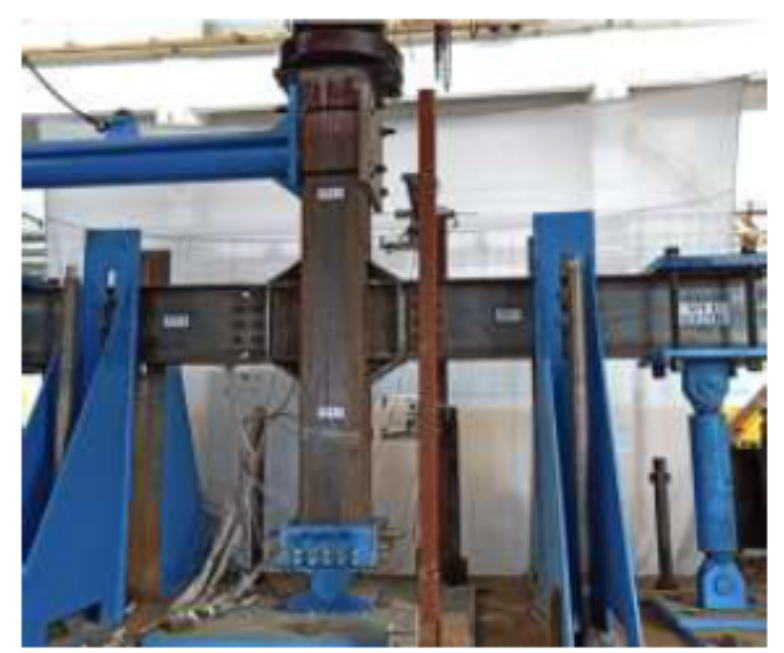

(b) Test site

Figure 2

Test apparatuses

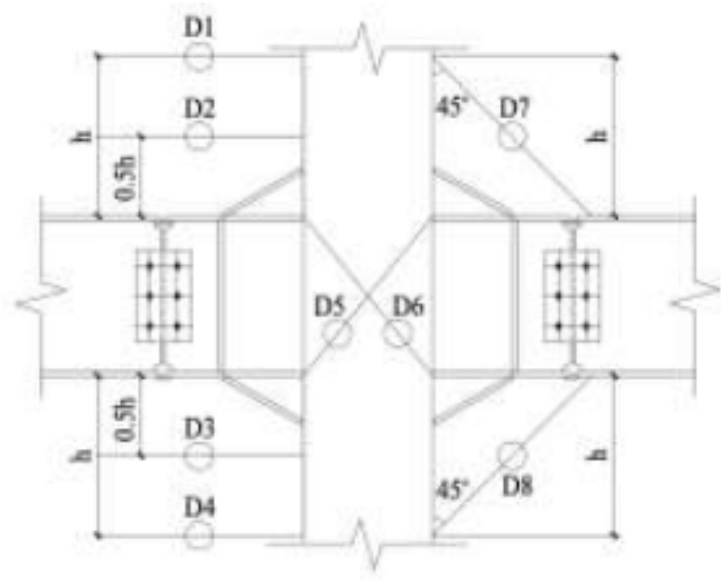

(a) Displacement meters

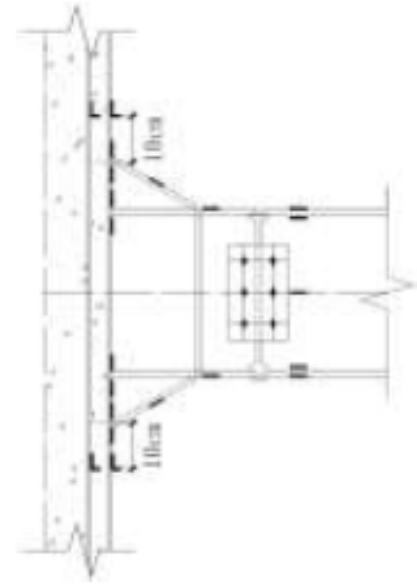

(b) Strain gauges

Figure 3

Layout of displacement meters and strain gauges 


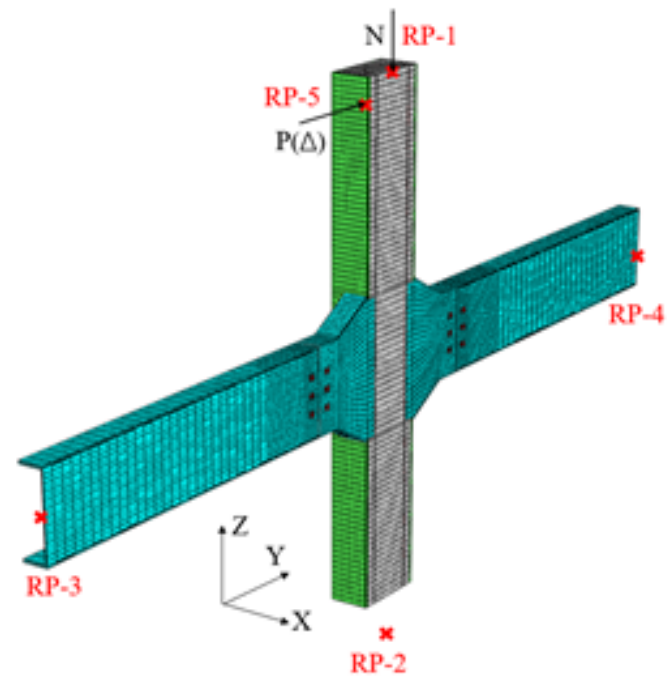

Figure 4

Overview of the half-model

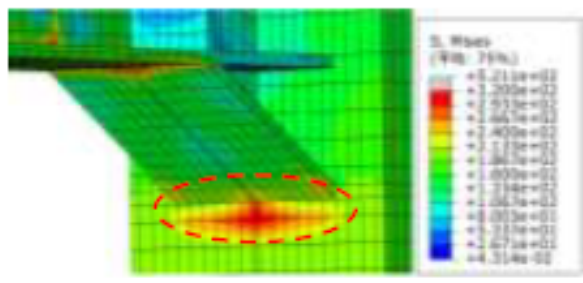

(a) Yielding at the junction between the lower haunch and the column
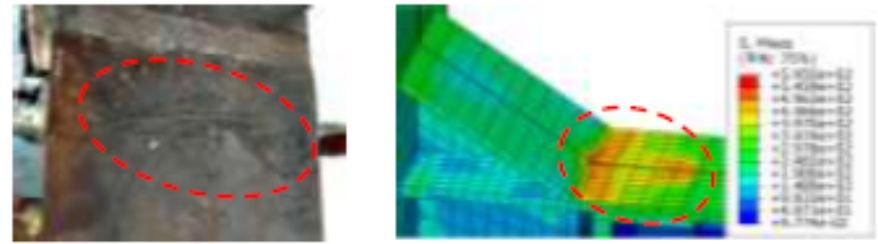

(b) Peeling phenomenon and the corresponding stress nephogram
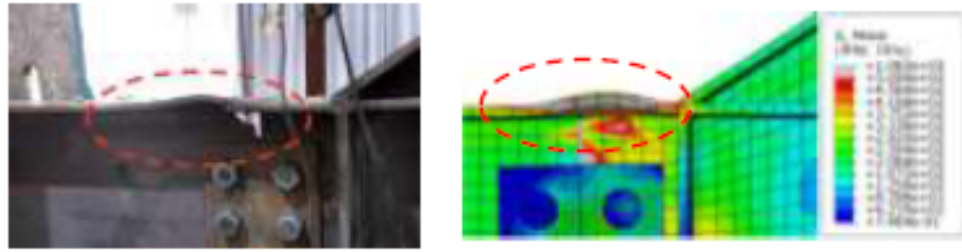

(c) Bulging beam flange and the captured phenomenon
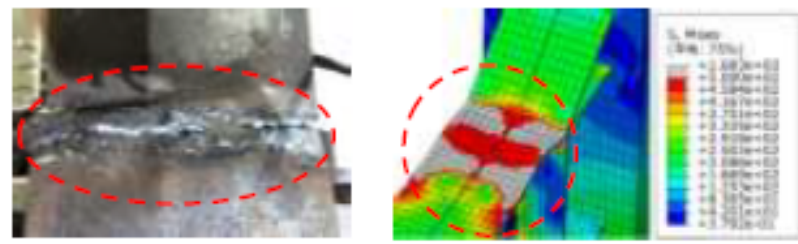

(d) Welding cracks and the corresponding stress nephogram

\section{Figure 5}



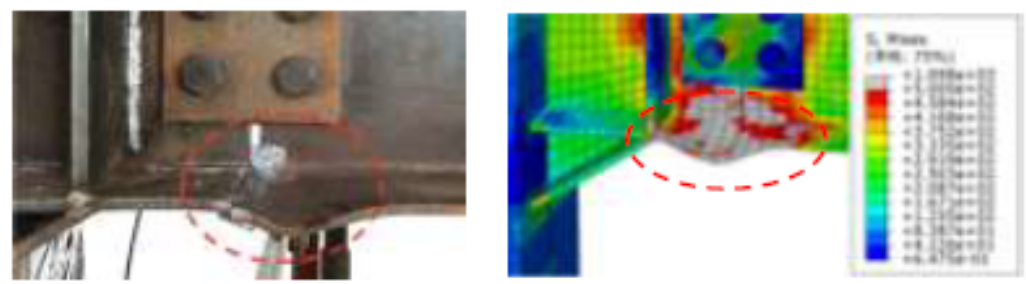

\section{Figure 6}

Final failure mode in the test and the FE simulation

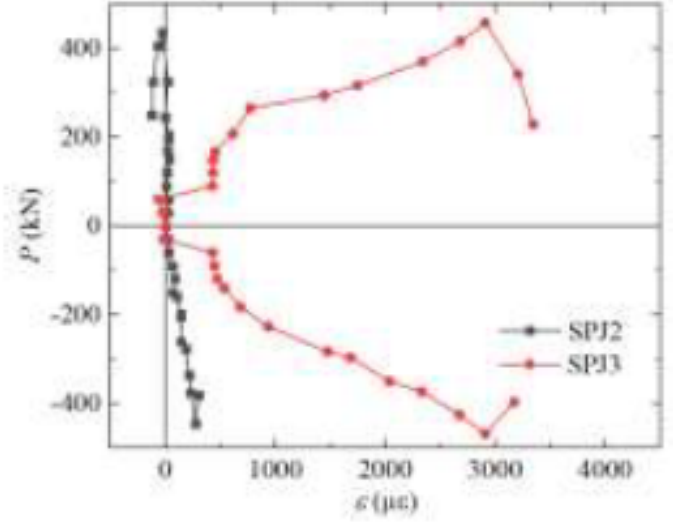

(a) Vertical strains

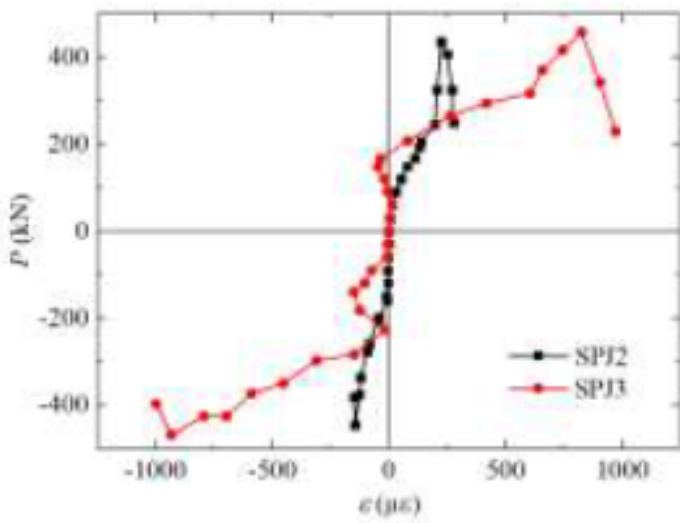

(b) Circumferential strains

Figure 7

$P-\varepsilon$ skeleton curves of inner steel tubes in the test

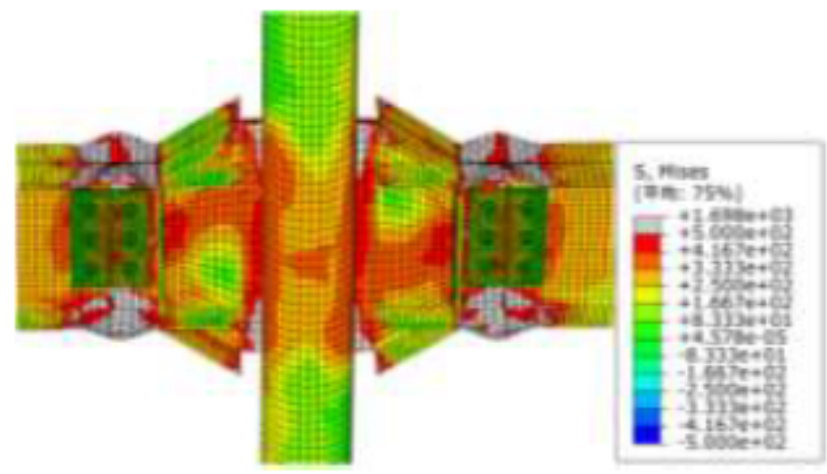

(a) SPJ2

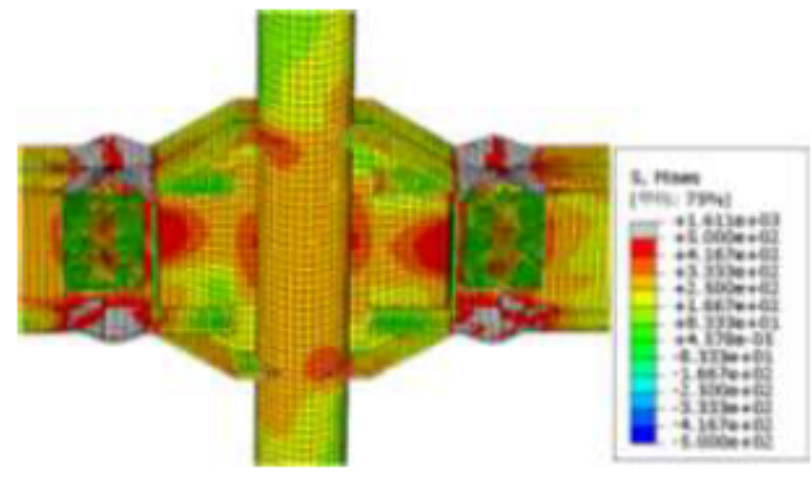

(b) $\mathrm{SPJ} 3$

Figure 8

Stress nephograms of the joint core area 


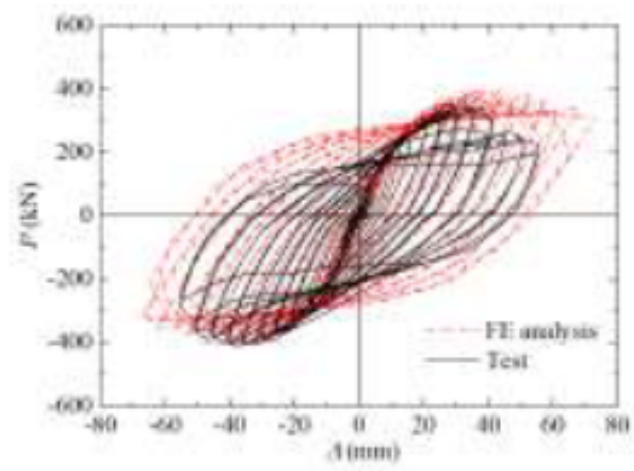

(a) SPJ1

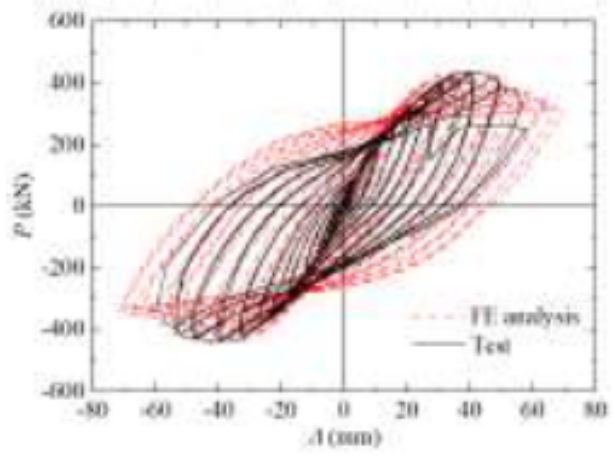

(b) SPJ2

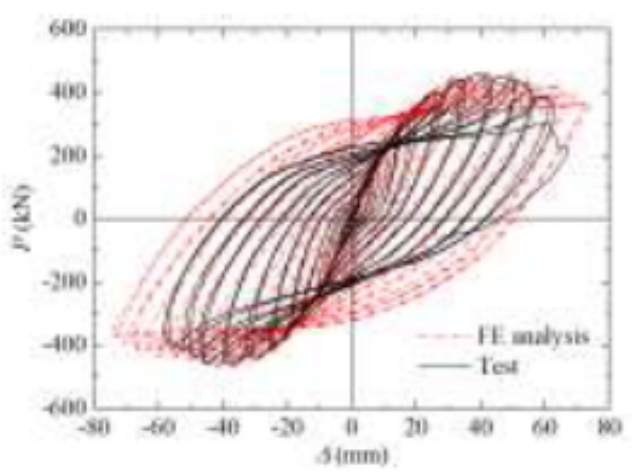

(c) $\mathrm{SPJ} 3$

\section{Figure 9}

Comparisons of $\mathrm{P}-\Delta$ hysteretic curves between tests and FE simulations

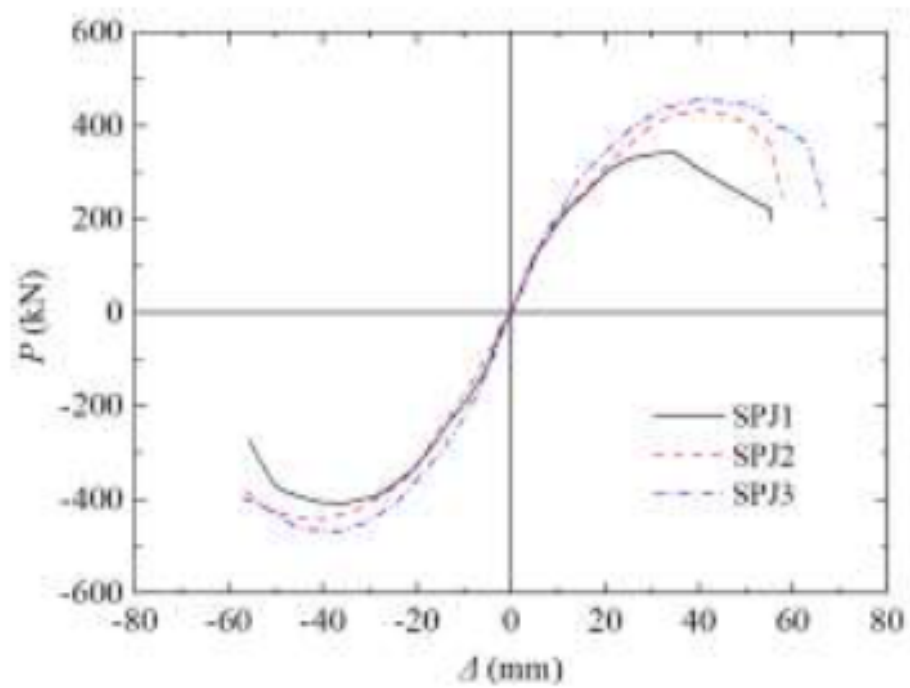

(a) Skeleton curves obtained from tests

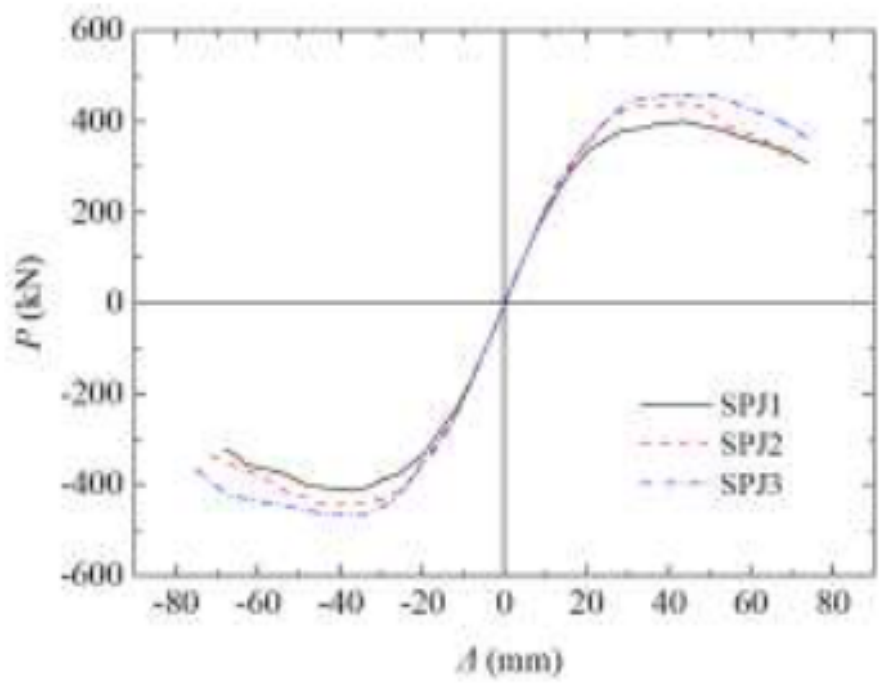

(b) Skeleton curves obtained from FE simulations

\section{Figure 10}

$\mathrm{P}-\Delta$ skeleton curves

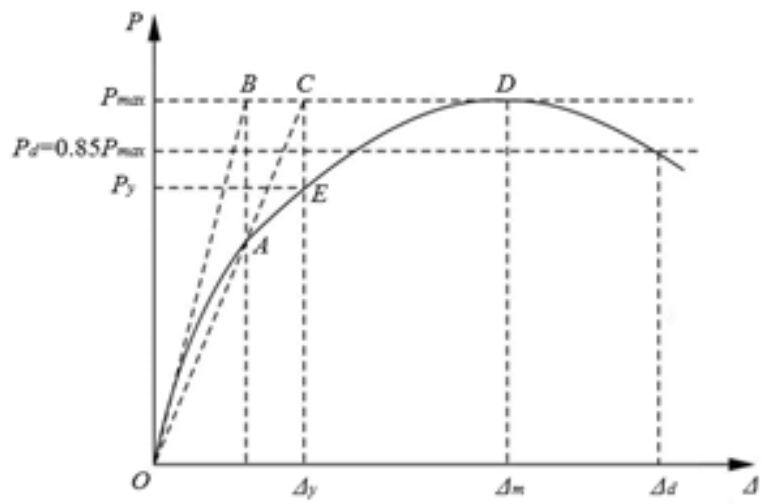

Figure 11 
Characteristic points in the typical P- $\Delta$ skeleton curve

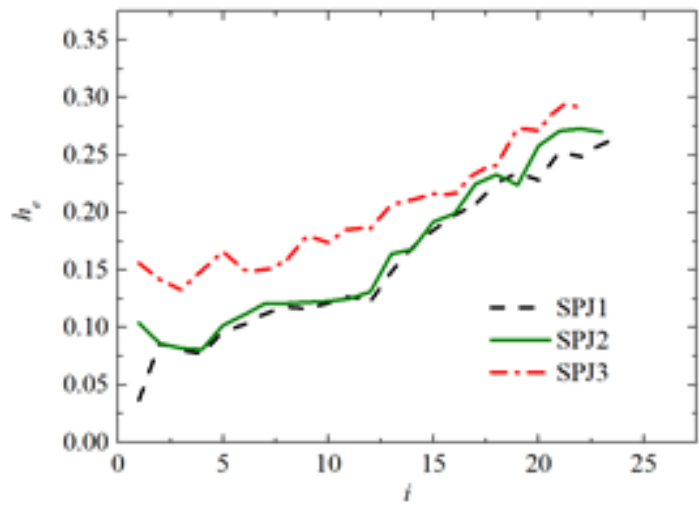

\section{Figure 12}

Changes of equivalent viscous damping coefficients (he) at each half-cycle number (i)

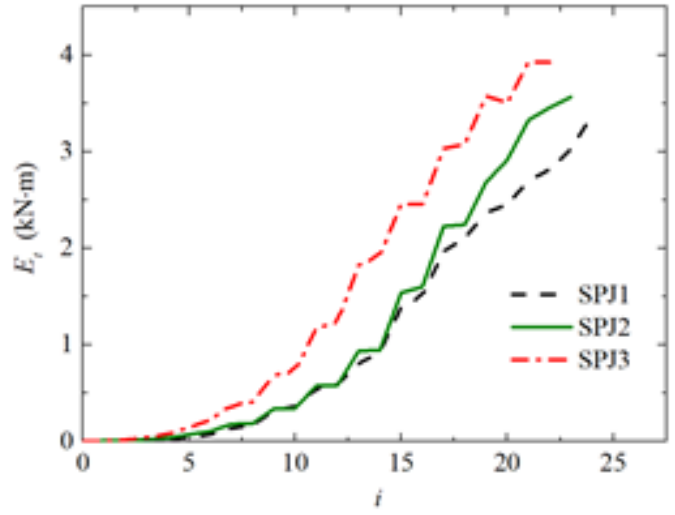

\section{Figure 13}

Changes of dissipated energy in a half-cycle (Et) at each half-cycle number (i)

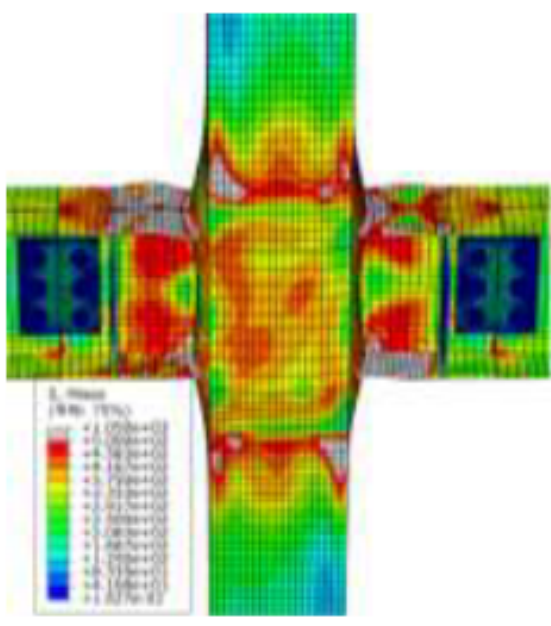

(a) Model SPJ2-HS

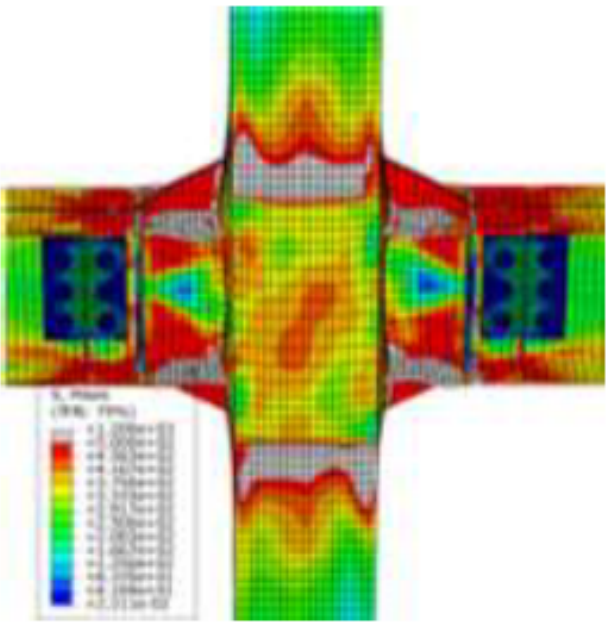

(b) Model SPJ2-H

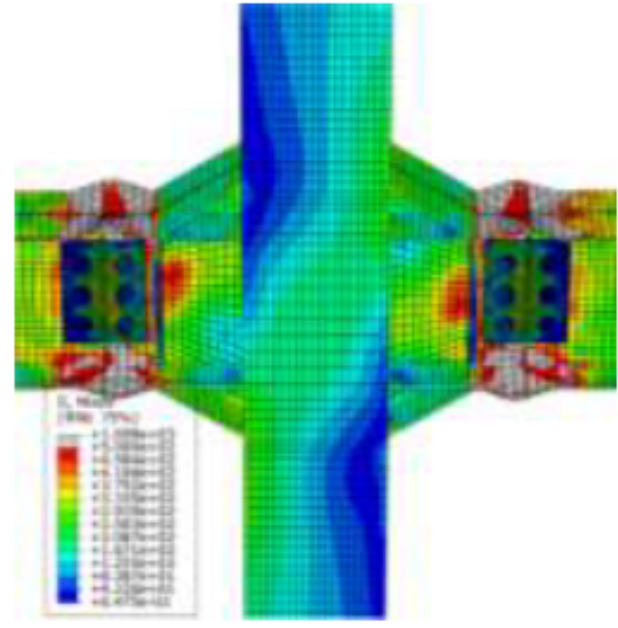

(c) Model SPJ2

\section{Figure 14}

Stress nephograms of joint models with different constructional details 


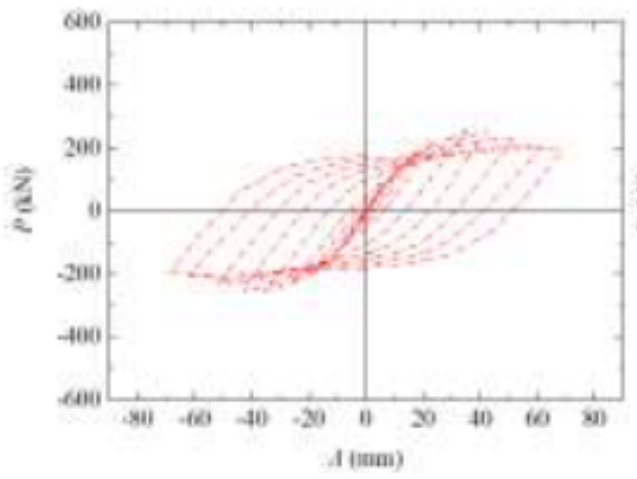

(a) Model SPJ2-HS

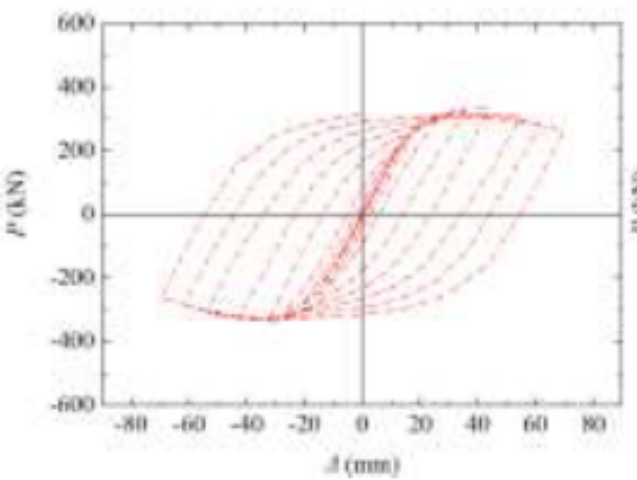

(b) Model SPJ2-H

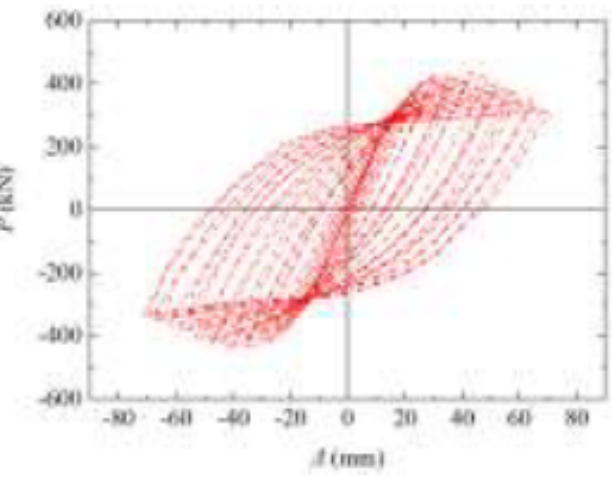

(c) Model SPJ2

\section{Figure 15}

P- $\Delta$ hysteretic curves of joint models with different constructional details

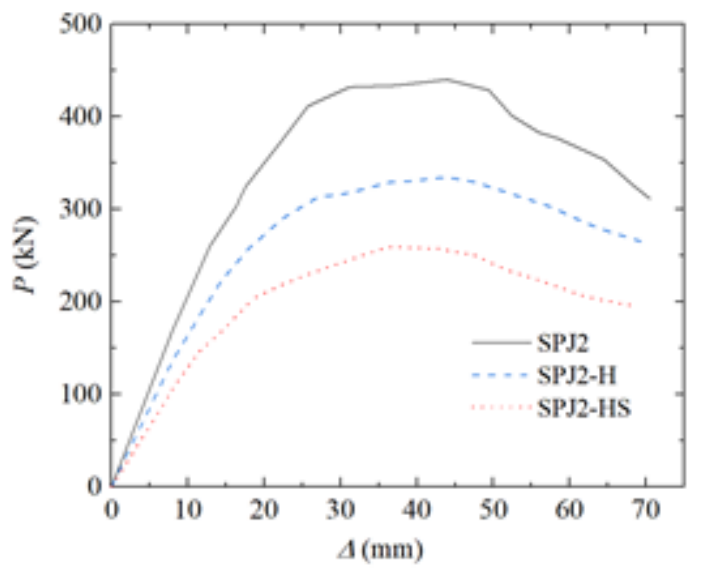

Figure 16

P- $\Delta$ skeleton curves of joint models with different constructional details

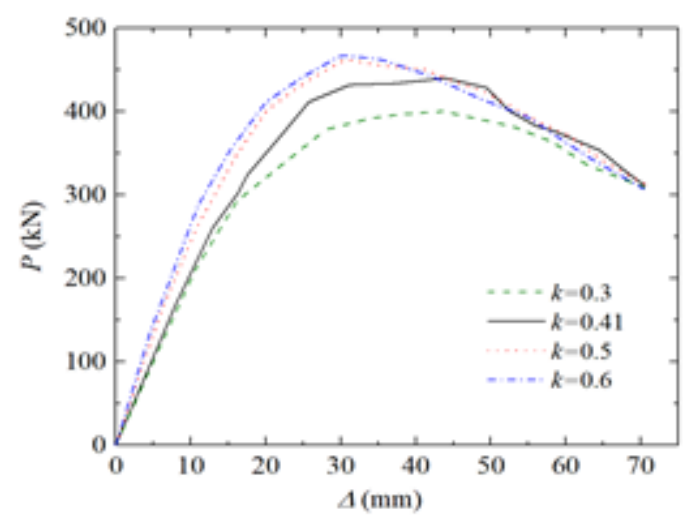

\section{Figure 17}

P- $\Delta$ skeleton curves of joint models with different beam-to-column bending stiffness ratios per unit length (k) 


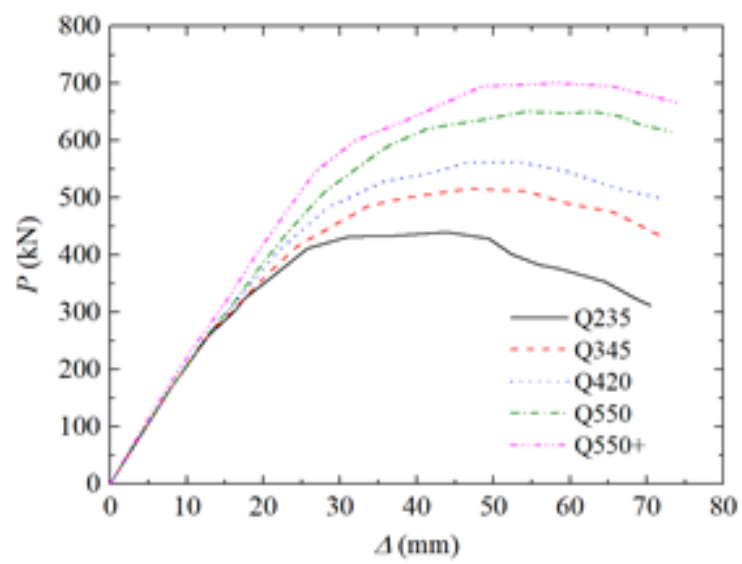

Figure 18

P- $\Delta$ skeleton curves of joint models with different steel beam strength

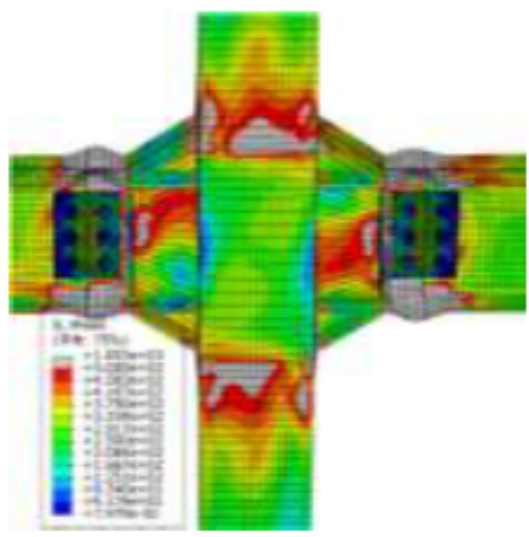

(a) Model Q420

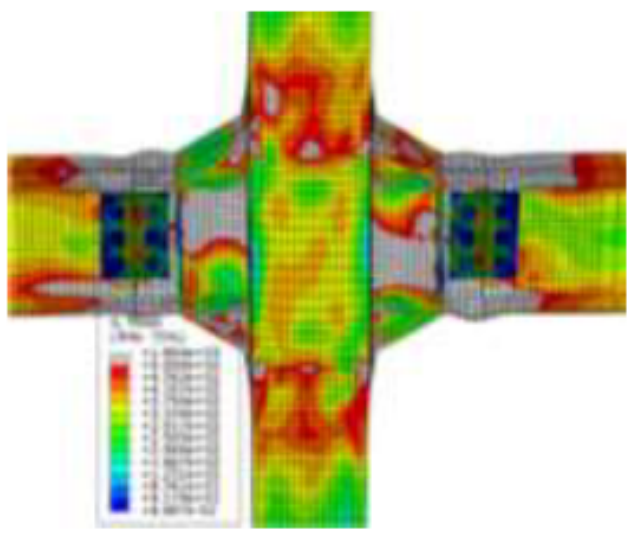

(b) Model Q550

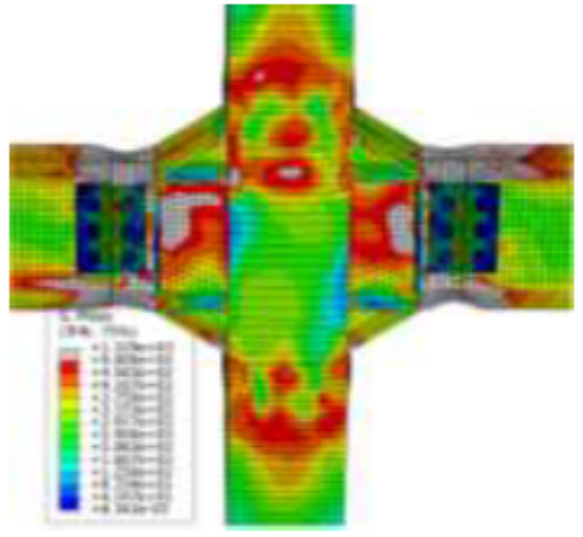

(c) Model Q550+

\section{Figure 19}

Stress nephograms of joint models with different steel beam strength

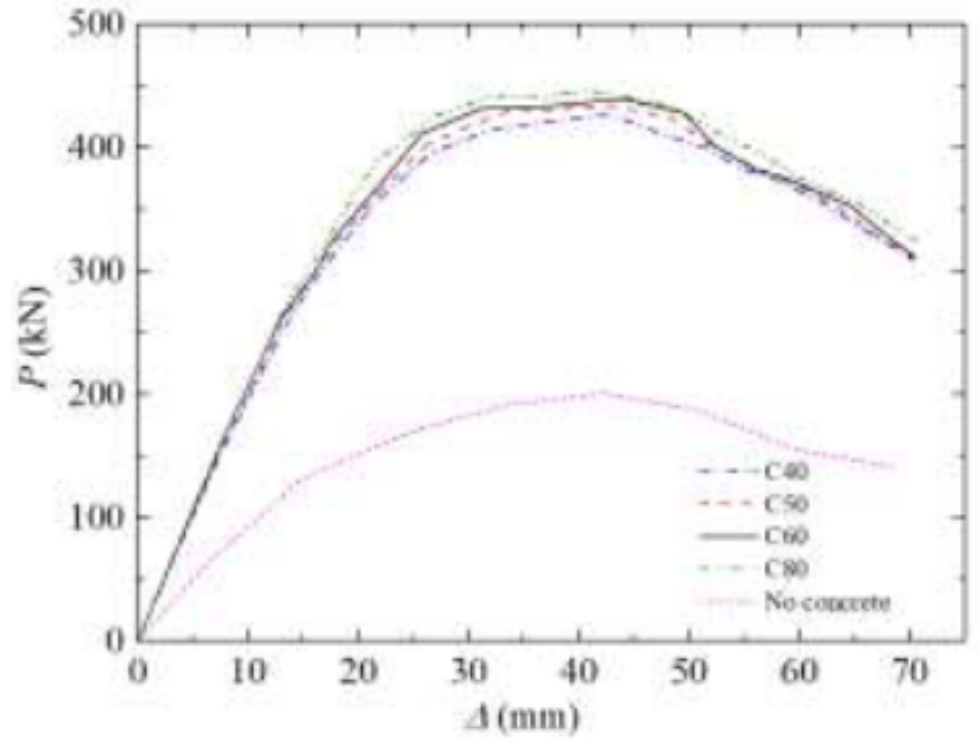


Figure 20

P- $\Delta$ skeleton curves of joint models with different concrete strength

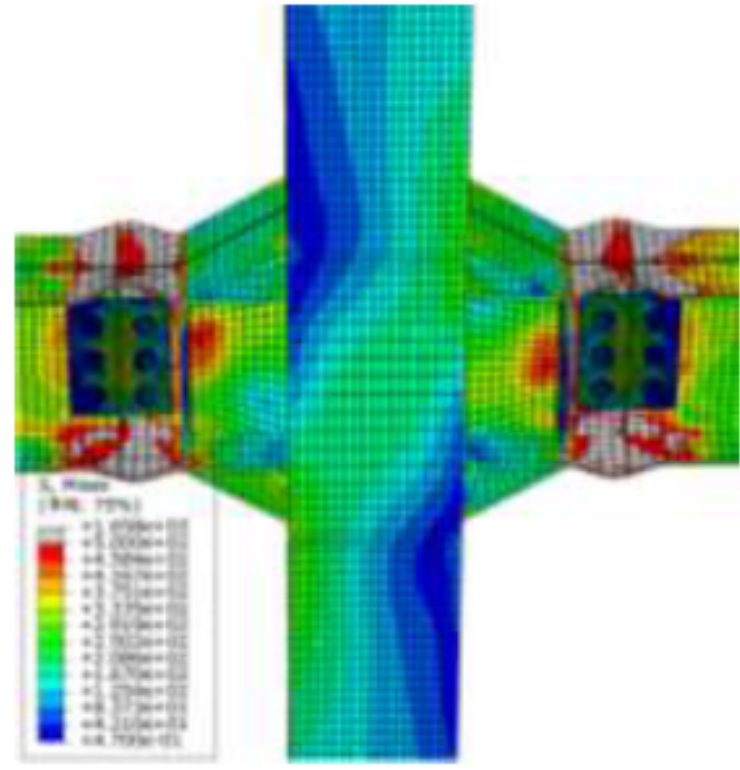

(a) Model C40

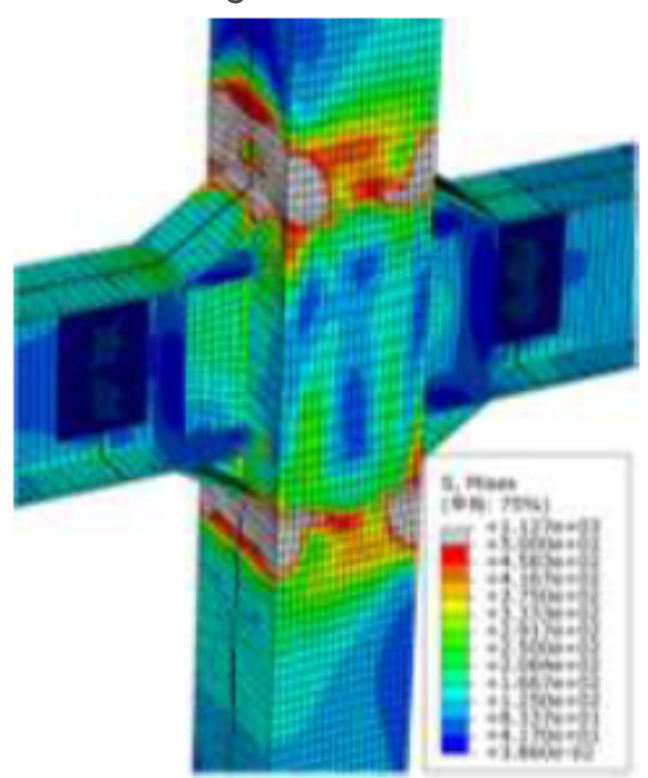

(b) Model No-concrete

\section{Figure 21}

Stress nephograms of joint models with different concrete strength

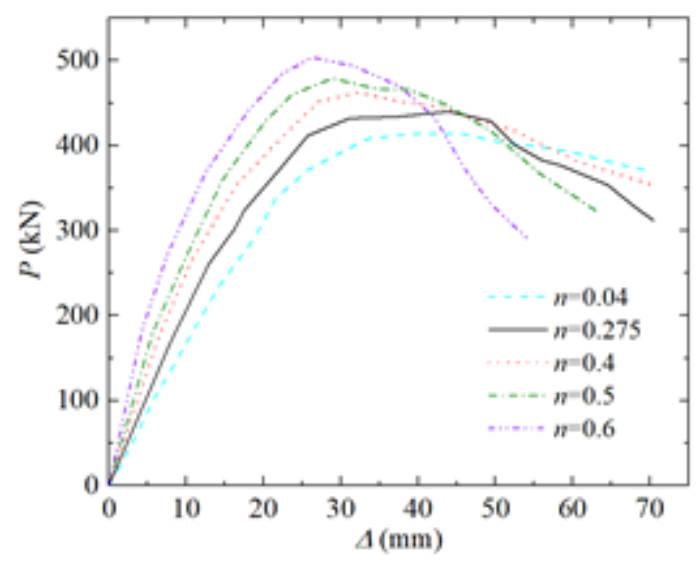

Figure 22

$\mathrm{P}-\Delta$ skeleton curves of joint models with different axial compression ratios ( $\mathrm{n}$ ) 


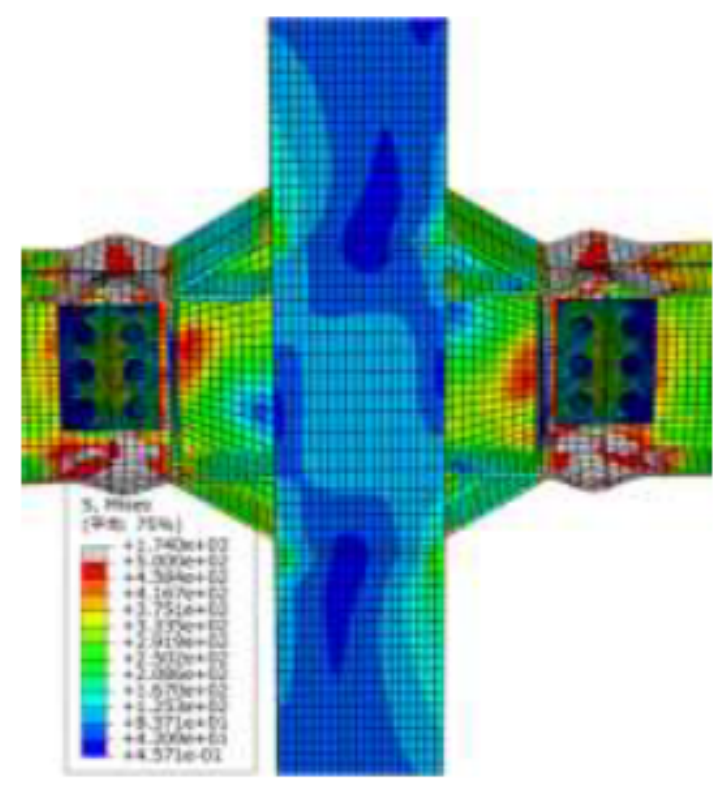

(a) $n=0.04$

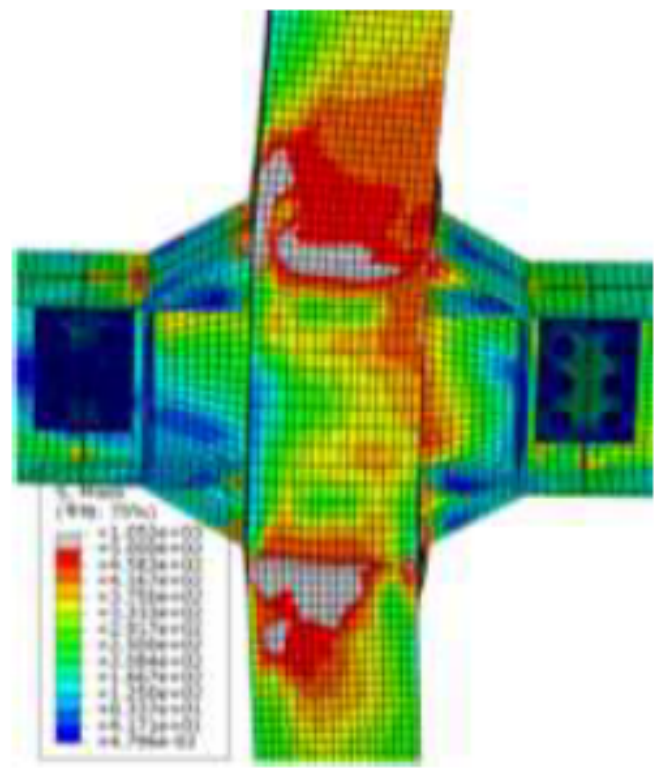

(b) $n=0.6$

Figure 23

Two typical failure modes of joint models with different axial compression ratios (n) 